\title{
THE CONCEPT OF MARKETING EFFORTS CONSOLIDATION AT THE GLOBAL CAR MARKET
}

\author{
Oleksandr Savych ${ }^{1}$, Tetiana Shkoda ${ }^{2}$ \\ ${ }^{1}$ Department of Marketing named after A. F. Pavlenko, Kyiv National Economic University named after \\ Vadym Hetman, 54/1 Peremogy Avenue, Kyiv, Ukraine \\ ${ }^{2}$ Department of Personnel Management and Labour Economics, Kyiv National Economic University \\ named after Vadym Hetman, 54/1 Peremogy Avenue, Kyiv, Ukraine \\ E-mails: ${ }^{1}$ savych@kneu.edu.ua; ${ }^{2}$ tnshkoda@ukr.net (correspondingauthor)
}

Received 28 February 2020; accepted 06 May 2020

\begin{abstract}
The purpose of the study is to research the peculiarities of the marketing concept development and form the concept of marketing efforts consolidation on the global car market. There are achieved the following principal objectives: 1) to research the evolution of marketing concepts; 2) to define the elements of the concept of marketing efforts consolidation; 3 ) to form the peculiarities and build the model of the concept of marketing efforts consolidation on the global car market. The results of the research are the created concept of marketing efforts consolidation on the global car market that is intended to accelerate sales and profits of car manufacturers as well as to be used by companies from different commodities markets. The method of systematic, critical and comparative analysis as well as synthesis and modeling method is employed.
\end{abstract}

Keywords: marketing efforts, consolidation, global car market, marketing policy, impact factors.

JEL Classification: F23, L62, M31.

\section{Introduction}

Today's global car market is an important component of the global economy, characterized by a complex commercial connections system, as well as the need to reconcile the actions of a large number of economic entities and their economic interests. Demand and supply fluctuations in this market can provoke economic crises and can slow the development of the world economy.

Marketing is constantly evolving with the development of the economy and economic relations, particularly in the global car market. The global economy and the car market are closely interrelated, and the growth of car sales is an impetus for the development of the economy of the countries of production and the global economy in general.

Cars production and sales in the world have been steadily increasing since 2009 for ten consecutive years after a global economic crisis, although now the pace has slowed down. Production reached 96 million units per year in 2018 (Wagner, 2020), and sales reached nearly 78.9 million cars in 2018 (SRD, 2020). Thus, if before the global crisis of 2008-2009 the average annual growth rate was $6.5 \%$, then after the crisis it was $3.7 \%$ (Savych, 2018). And this figure decreases annually. Currently, there is already a sharp decline in sales and production due to the stagnation of the Chinese economy, on one hand, and to COVID-19 events, on the other hand, which caused even stoping of cars' production in Europe.

Research on the marketing activities of enterprises on the car market and prospects of their effective functioning is one of the important components of the development of modern business, which can not be successfully carried out without studying the world experience. Therefore, it is necessary to take into account globalization processes (Semyrak, 2016), restrictions on access to natural resources and increase of their value (Terletska, 2018), digitalization of the society (Shevchenko, 2019), intensification of competition (Tomyuk, 2016) and state regulation (Savych, 2017), which are the key factors of the development of the automotive industry in the world.

On one hand, there is a set of publications in the scientific literature devoted to the marketing concept (Elliott, 1990; Morgan, 1996; Svensson, 2001; Taqi et al., 2019). On the other hand, researchers pay attention to the relations with suppliers and consumers in the automotive industry (Demirbas et al., 2018; Bagul \& Mukherjee, 2019; Sarkar \& Rajagopalan, 2018). But, there is a research gap connected with the absence of the mar- 
keting concept, which reflects the peculiarities of the global car market. It is the research problem of our article, which has to be solved here.

Consequently, the purpose of our article is to investigate the peculiarities of the marketing concept development and form the appropriate concept of consolidation of marketing efforts at the global car market.

To achieve this purpose, the authors identified the following objectives: 1) to study the evolution of marketing concepts; 2) to identify the components of the concept of consolidation of marketing efforts; 3) to form the features of the concept of marketing efforts consolidation at the global car market.

The method of systematic, comparative and critical analysis is used for the theoretical background section of our research. Besides, the synthesis and modeling method is used for the results section, where the model of the concept of marketing efforts consolidation of car producers at the global car market is presented.

\section{Theoretical background}

\subsection{The genesis of marketing}

Considering that car manufacturers are industrial enterprises, theoretical questions and results of research of the marketing of industrial enterprises, which are stated in the works of many scientists, are important for our research. Of particular importance are the works of Ambler (2004), Assael (1993), Kotler and Keller (2015), Kerin, Hartley, and Rudelius (2012), Lambin (1992), Pavlenko and Voychak (2003), Pylypchuk and Dannikov (2011), Fedorchenko (2009), etc.

Marketing is one of the important components of modern business development. The main purpose of marketing is to achieve the goals set by the company and maximize the obtained profits. From this, there is a need for the company to receive reliable data on the current market situation, including, determine the prospects for its growth. On the other hand, it identifies the needs and preferences of its clients. An equally important goal of the company is to choose a promising strategy for its development. Therefore, there is a need for a comprehensive study of the stages of marketing development, that is, its genesis, which will enable us to determine the most promising concept and improve the company's competitive ability.

The concept of marketing is a management philosophy that promotes the profitability of producers by meeting the needs of consumers by fo- cusing on the long-term and flexible definition: business activity, market, consumer target groups and main strategic goals (Zavjalov, 2014). Or, by Jobber and Ellis-Chadwick (2012), the concept of marketing is the process of achieving corporate goals, at the expense of better meeting the needs of consumers. This is precisely that the concept of marketing differs from the concept of sales, although sales are one of the functions of marketing (Al Badi, 2019).

Since its inception, the concept of marketing has come a long way in evolutionary development. The knowledge of stages is not only of historical importance, but it also allows you to understand the logic of marketing development and correctly choose the necessary marketing concept of the enterprise and prepare for the transition to the next, more developed conceptual marketing base of development (Pavlenko \& Voychak, 2003).

The main task of marketing of the past was to respond to changes in the environment of market actors, and today, in contrast to the past, in the forefront there is relationship marketing, that is, the relationship between buyers and sellers.

In the past, scholars such as Weber, Parsons, and Henderson (1964) considered functional specialization, standardization, universalization, cooperation and division of labor as the basis of effective organization. Functional approach principles have certainly worked and are working in the industrial-type economy. However, in today's economic realities, business entities are forced to seek effective approaches to the organization and management of the enterprise, based on an in-depth definition of consumer demand, needs and requests as driving factors for the production of goods and services.

Research into the origins of marketing should start from the early stages of the emergence of capitalism, the revitalization of commodity-money relations, and the period of initial accumulation of capital.

By classification of Kotler (2002), there are five concepts in marketing history:

1) production improvement;

2) product improvement;

3 ) intensification of commercial efforts;

4) marketing;

5) social and ethical marketing.

We believe that the first three concepts of marketing, by Kotler (2002) is a pre-marketing concepts. The ideology of marketing is a natural final result of the development of economic thought in market research, and his initial research is considered by many scholars to be mercantilism. 
Mercantilists derived the source of wealth from the non-equivalent (unjust) exchange (Zaytsev \& Moskalenko, 2018), however, the further evolution of the market economy leads to other theories.

The second source of marketing is a classic political economy. Such marketing concepts as the concept of productivity improvement and the concept of product improvement are based on classical political economy. Legislators of the classical political economy of the XVI-XIX centuries such as W. Petty, A. Smith, D. Ricardo, K. Marx considered wealth as a source of production (Zaytsev \& Moskalenko, 2018), and the basis of exchange was the law of value, that is, equivalent exchange.

Scientific research on marketing appeared in the early XX century since the moment of the marketing concept formation.

The stage of development of a marketing concept, oriented to production, is characterized by the focus of marketing on increasing production volumes of products of a limited range, increasing production capacity.
There is no consensus on the further development of marketing among scientists, but this is due to the complexity of understanding the term "marketing" and its acquisition of many elements and directions of development. The analysis of literary sources allowed us to classify the current approaches of leading scientists to the periodization of marketing concepts (Table 1).

The production concept was replaced by a concept whose priority was to improve the quality of the products being manufactured. The main task for manufacturers who adhere to this concept is the endless improvement of the consumer properties of the product, its modernization, and the improvement of characteristics. Subsequently, the product concept was transformed into the sales concept (Kotler \& Keller, 2015) or the concept of intensification of commercial efforts (Kotler, 2002), the main purpose of which is to force the consumer to opt for a single product among a wide range of products of numerous manufacturers that do not have fundamental differences.

Table 1. Key marketing concepts and scientific approaches to its application in enterprise management (source: structured by the authors based on Ambler (2004), Assael (1993), Boone and Kurtz (2013), Kotler (2002), Kotler and Keller (2015), Lambin (1992), Kerin, Hartley, and Rudelius (2012))

\begin{tabular}{|c|c|c|c|c|c|c|c|}
\hline Period & Ph. Kotler & $\begin{array}{l}\text { Ph. Kotler, } \\
\text { K. L. Keller }\end{array}$ & T. Ambler & H. Assael & $\begin{array}{l}\text { J. J. Lam- } \\
\text { bin }\end{array}$ & $\begin{array}{l}\text { R. Kerin, } \\
\text { S. Hartley, } \\
\text { W. Rudelius }\end{array}$ & $\begin{array}{l}\text { L. E. Boone, } \\
\text { D. L. Kurtz }\end{array}$ \\
\hline till 1900 & \multirow{3}{*}{$\begin{array}{l}\text { Concept of } \\
\text { production } \\
\text { improvement }\end{array}$} & \multirow{3}{*}{$\begin{array}{l}\text { Production } \\
\text { concept }\end{array}$} & & \multirow{4}{*}{$\begin{array}{l}\text { Orientation } \\
\text { to produc- } \\
\text { tion }\end{array}$} & \multirow{6}{*}{$\begin{array}{l}\text { Product } \\
\text { concept }\end{array}$} & \multirow{4}{*}{$\begin{array}{l}\text { Era of pro- } \\
\text { duction }\end{array}$} & \multirow{3}{*}{$\begin{array}{l}\text { Era of } \\
\text { production }\end{array}$} \\
\hline 1900-1910 & & & & & & & \\
\hline 1910-1920 & & & & & & & \\
\hline 1920-1930 & $\begin{array}{l}\text { Concept of } \\
\text { product im- } \\
\text { provement }\end{array}$ & $\begin{array}{l}\text { Product con- } \\
\text { cept }\end{array}$ & & & & & \multirow[t]{3}{*}{ Era of sales } \\
\hline 1930-1940 & \multirow{2}{*}{\begin{tabular}{|l|} 
Concept of \\
intensification \\
of commercial \\
efforts
\end{tabular}} & \multirow[t]{2}{*}{ Sales concept } & & \multirow{2}{*}{$\begin{array}{l}\text { Orientation } \\
\text { to sales }\end{array}$} & & \multirow[t]{3}{*}{ Era of sales } & \\
\hline $1940-1950$ & & & & & & & \\
\hline $1950-1960$ & \multirow[t]{4}{*}{$\begin{array}{l}\text { Concept of } \\
\text { marketing }\end{array}$} & \multirow[t]{4}{*}{$\begin{array}{l}\text { Marketing } \\
\text { concept }\end{array}$} & $\begin{array}{l}\text { Neoclassi- } \\
\text { cal para- } \\
\text { digm }\end{array}$ & \multirow[t]{2}{*}{$\begin{array}{l}\text { Orientation } \\
\text { to customers }\end{array}$} & \multirow[t]{2}{*}{$\begin{array}{l}\text { Sales con- } \\
\text { cept }\end{array}$} & & \multirow[t]{4}{*}{$\begin{array}{l}\text { Era of mar- } \\
\text { keting }\end{array}$} \\
\hline 1960-1970 & & & \multirow{3}{*}{$\begin{array}{l}\text { Strategic } \\
\text { approach }\end{array}$} & & & \multirow{3}{*}{$\begin{array}{l}\text { The era of the } \\
\text { marketing } \\
\text { concept }\end{array}$} & \\
\hline $1970-1980$ & & & & $\begin{array}{l}\text { Orientation } \\
\text { to competi- } \\
\text { tion }\end{array}$ & $\begin{array}{l}\text { Strategic } \\
\text { marketing }\end{array}$ & & \\
\hline 1980-1990 & & & & \multirow{3}{*}{$\begin{array}{l}\text { The strate- } \\
\text { gic concept } \\
\text { of market- } \\
\text { ing }\end{array}$} & & & \\
\hline 1990-2000 & \multirow{2}{*}{$\begin{array}{l}\text { Concept of } \\
\text { social and } \\
\text { ethical mar- } \\
\text { keting }\end{array}$} & \multirow{2}{*}{$\begin{array}{l}\text { Holistic mar- } \\
\text { keting con- } \\
\text { cept }\end{array}$} & \multirow{2}{*}{$\begin{array}{l}\text { Relation- } \\
\text { ship mar- } \\
\text { keting }\end{array}$} & & \multirow{2}{*}{$\begin{array}{l}\text { Market- } \\
\text { oriented } \\
\text { manageme } \\
\text { nt }\end{array}$} & \multirow{2}{*}{$\begin{array}{l}\text { The era of } \\
\text { market orien- } \\
\text { tation }\end{array}$} & \multirow{2}{*}{$\begin{array}{l}\text { Era of rela- } \\
\text { tions }\end{array}$} \\
\hline after 2000 & & & & & & & \\
\hline
\end{tabular}


The sales concept has been replaced by the marketing concept, whose main task is to maximize customer satisfaction and stimulate demand. The modern concept of marketing, which has replaced marketing one, is defined by various scientists as social and ethical (Kotler, 2002), holistic (Kotler \& Keller, 2015), the concept of relationship marketing (Ambler (2004), Hoffman and Bateson (2010), the era of relations (Boone \& Kurtz, 2013), etc. As with the marketing concept, customer satisfaction is at the forefront, while taking into account the interests of the society and all actors involved in product creation.

\subsection{Modern marketing concept}

The most important goal of modern marketing is to identify new, unmet needs, and further focus on the enterprise to meet not only existing demand but also to create and stimulate new markets and consumer needs. This is why effective efforts to meet consumer demand make it possible to compete effectively in the market. Today, most businesses believe that the sales market is a core element of their business model. Any company operates in the market and conducts its activity under its direct influence. Therefore, here marketing is the basis of enterprise management and focuses all efforts of enterprises on gaining the maximum share of the sales market.

According to Kotler and Keller (2015), a modern marketing concept, reflects the firm's commitment to consumer sovereignty, an orientation to consumer needs, supported by complex marketing efforts aimed at creating consumer satisfaction as a basis for achieving the organization's goals.

Therefore, the concept of marketing is an external-internal perspective. Firstly, it is necessary to identify the target markets and focus on the needs of the consumer. To apply this concept, it is advisable to apply a list of actions that directly affect the behavior of the buyer and his preference for a product or service that is manufactured or sold by a particular business. As a result of such actions, it is the profits maximization of the enterprise and achievement of the set goals, which follows from the satisfaction of the needs of consumers.

The basis of the modern approach realization is relationship marketing. Such an approach is aimed at establishing and developing successful relationships with suppliers, customers and external partners. An indispensable condition for relationship marketing is the formation of mutual trust and commitments between firms. Relationship marketing (RM) is described as affiliate marketing, engagement marketing, interaction market- ing, marketing of partnership relations (Pylypchuk \& Dannikov, 2011). Companies influence not only their relationships with direct partners, but they can and usually make some influence on their relationships with other entities. Thus, the active environment of the company consists of direct and indirect relationships, partners and third parties, which indicates the need to study not only the direct contacts of the central organization but also its indirect relationships. So, the essence of relationship marketing is to establish close relationships with the various participants in the process of production and sale of goods (services) to present at the market to consumers, which brings profit to all participants of the process and meets consumers' satisfaction (Dannikov, 2011).

The final result that relationship marketing seeks is the formation of the unique asset of the company, called the marketing business network, which includes the company and interested in its workgroups (contact audiences): consumers, employees (personnel), suppliers, distributors, retail merchants, advertising agencies, university scientists, and anyone with whom the organization has established mutually beneficial business relationships. Thus, not separate manufacturers compete at the market, but rather business systems compete as a whole. In this case, the company that managed to build the most efficient system wins. Spiro, Stenton, and Rich (2007) believe that relationship selling differs from transaction selling, where sellers are only interested in direct sales of a product or service (one-time deal).

It should be noted that with the development of relationship-driven sales, there are, of course, costs associated with the improvement of loyal customer service, but also some benefits that extend to wider areas of cooperation.

At present, the concept of social and ethical marketing is increasingly focused on the economies of developed countries. It argues that the goal of marketing in all business sectors is to identify the shortcomings, needs, and interests of the target markets and to provide the desired satisfaction more efficiently and productively than competitors while maintaining or enhancing the well-being of the consumer and society as a whole. That is what distinguishes this approach from the traditional view of marketing, which avoids the problem of possible conflicts between the desire of the seller to sell their products and the long-term well-being of the consumer. Now, when making decisions, companies start thinking about the interests of society. The concept of socially-oriented, ethical 
marketing requires balancing the following three factors:

- companies' profits;

- consumers' requests and demands;

- society interests.

The concept of socially-oriented, responsible marketing firstly emerged in the field of commodity production (Fedorchenko, 2009). However, this is relevant not only for commodity producers but also for the services sector.

The need to use marketing as a kind of philosophy that permeates the entire business of the company has transformed the perception of marketing as a management concept, a business concept into holistic marketing. In this case, consumers, the company itself and its partners are involved in marketing. With their participation the market space and potential opportunities that arise in it for the company are determined. Then the potential opportunities, the demands of focusing on the consumers are translated into the language of the necessary resources, the use of key competences and the creation of a network of cooperation.

Marketing, in this case, is the whole philosophy of the company - it is provided for an integral approach to it, the whole company is engaged in marketing, including a special team, not only the "profile" department.

The need for effective marketing decisions in overcoming contradictions (finding a compromise) in the interaction of economic entities and the optimal placement of resources, require changes in the nature of enterprise marketing and business orientation to a new modern concept created by the classics of marketing Kotler and Keller (2015) is a so-called "holistic marketing" that includes four components:

- market orientation marketing;

- socially responsible marketing;

- integrated marketing (products, prices, sales, communications);

- internal marketing.

To implement socially responsible behavior, a business should have the ability to make independent decisions (without coercion); understanding the consequences of self-made decisions; the ability to see the goals and meaning of business development in the context of social development; the desire to make decisions that contribute to the development of society.

Integrated marketing involves the mutual coordination of the traditional tools of the marketing complex to maximize their overall effect. Internal marketing ensures acceptance of marketing principles by all employees of the organization, that is, adherence to marketing philosophy of business at the company level as a whole: to pay special attention to the quality of work of personnel, to effectively train and motivate employees who work with clients, as well as all servicing and consulting staff to work in a team and provide customer satisfaction.

It has to be noted, that the existing marketing concept is mainly dedicated to theoretical approaches to an understanding of "marketing" especially in case of application these studies to real new business frames of enterprises' marketing activities where real business is living while combining off-line and on-line activities. Thus, the ground of new marketing concepts development is arising from practical business nowadays.

While studying the world evolution of marketing concepts, it should be noted that the essential criteria that should be guided in choosing a marketing concept for an organization within a country are several factors that determine the situation in a particular market segment and the choice of the optimal marketing strategy.

There are the following main factors for determining the situation at the selected market (Savych, 2018):

- needs of stakeholders - consumer, manufacturer, state, society, etc. The level of their satisfaction and the ability to create new needs in the selected market;

- external and internal factors of the organization that have an impact on the market;

- national or regional mentality;

- a vector of change in the political, economic, technological, social and legal environment.

Based on the study of the theory of marketing concept development, we propose the author's periodicity of development of the theory of marketing concept (Figure 1).

Thus, we believe that many scientists did not include the stage that preceded the production and / or product concept. The authors propose to name this stage of marketing development as the period of a simple trade. Also, in marketing theory, we propose to divide the stage of marketing concept into 2 stages: the period of marketing development within individual departments of companies and the stage when marketing became the basis of all activity of the enterprise. And today, with the development of new technologies and Internet marketing (Radionova-Girsa, 2018), when almost all the activities of enterprises have moved to the Internet and companies can communicate directly with each client, a new stage of marketing development is coming - the digital era. 


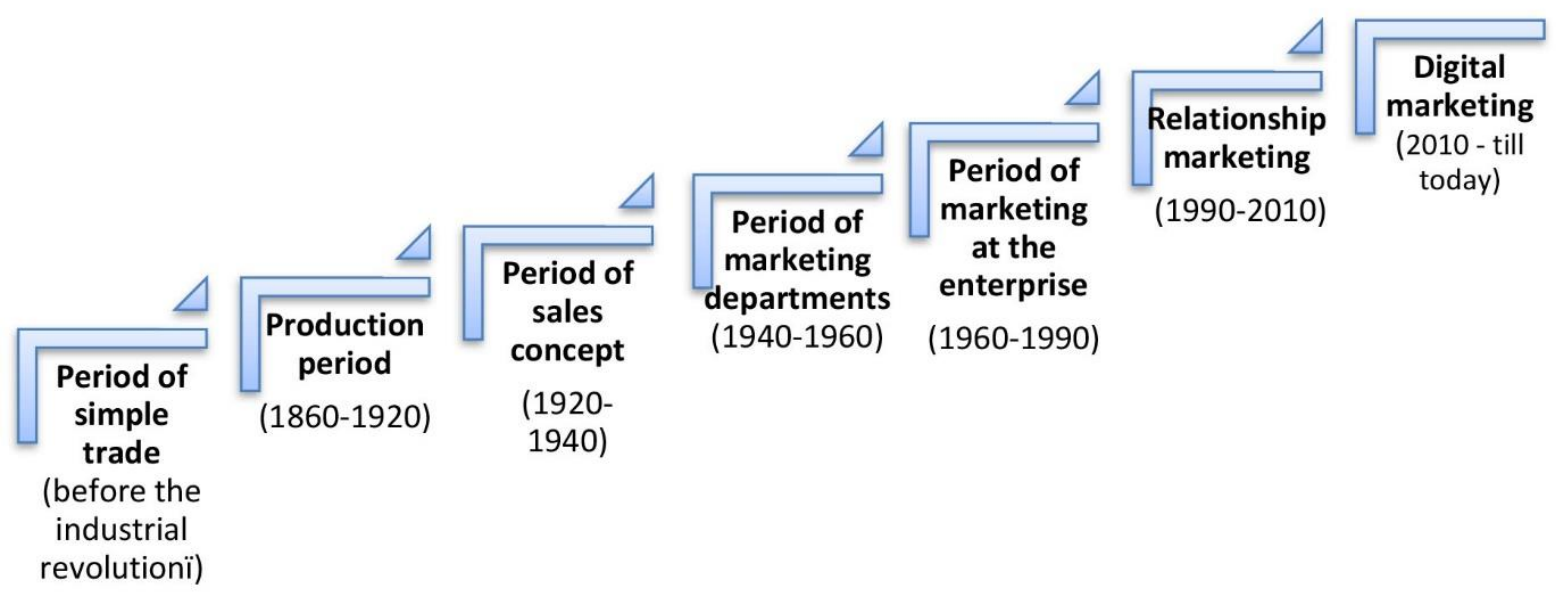

Figure 1. Evolution of marketing concepts (source: composed by the authors)

\section{Results}

As a result of our research, taking into account the analysis of marketing concepts made earlier, we consider that it is advisable to offer an author's approach to the concept of marketing efforts consolidation by its components under the influence of characteristic features of demand in international car markets in the context of globalization of world economic processes, informatization of economy and the high cost of natural resources, increasing requirements for environmental friendliness, ergonomics, and car safety, and urbanization of the population, taking into account changes in consumer tastes and consumer preferences in different geographic markets and across generations.

"Consolidation" means merging and consolidating around one single idea - the buyer's decision to buy.

We have investigated the evolution of marketing concepts, their transformation and found that in the present conditions of doing business under the influence of globalization and informatization processes, consolidation of methodical and methodological principles in the process of marketing management at the enterprises of the global industry production of cars is relevant. The consolidation of marketing efforts, first and foremost, is aimed at identifying the demand and satisfaction of the world car market, taking into account national, economic, environmental, geographical, historical and other conditions in each of the markets. The consolidation of marketing efforts in the context of globalization implies taking into account the consumer needs and opportunities of the global aggregate consumer to buy goods and services within their capacity in the amount of nomenclature offered in the world markets following the "offer" of national car manufacturers within their capabilities.

The use of marketing efforts consolidation in the management of global car manufacturers opens the opportunity to reduce the impact of fierce competition in international markets, focusing on the growing demands of buyers for quality of goods and after-sales service, by enhancing the strategic impact of the tools of the marketing standard, not only globally but also by effectively integrating local features of regional cluster markets into a global one.

From our point of view, a system approach and integrity are required to influence the buyer's decision to buy a particular product. Some marketing tools no longer work. Moreover, the marketing complex is influenced by external impact factors at the strategic and tactical levels. The marketing complex formed under the external influence in its turn pushes the buyer to buy and builds his loyalty. So, we propose to apply the concept of marketing efforts consolidation, the essence of which is to form such a marketing complex, which would take into account the impact factors at the micro and macro levels. And there would be the use of such marketing tools, which is dictated, on the one hand, by a dynamic global external non-controlled environment and consumers behaviour, and by efficient business processes - on the other hand. Therefore, from our point of view, the marketing decision of the enterprise, which is developed under the impact factors at the strategic and tactical levels, is directly influenced by the consumer's decision (Figure 2). 


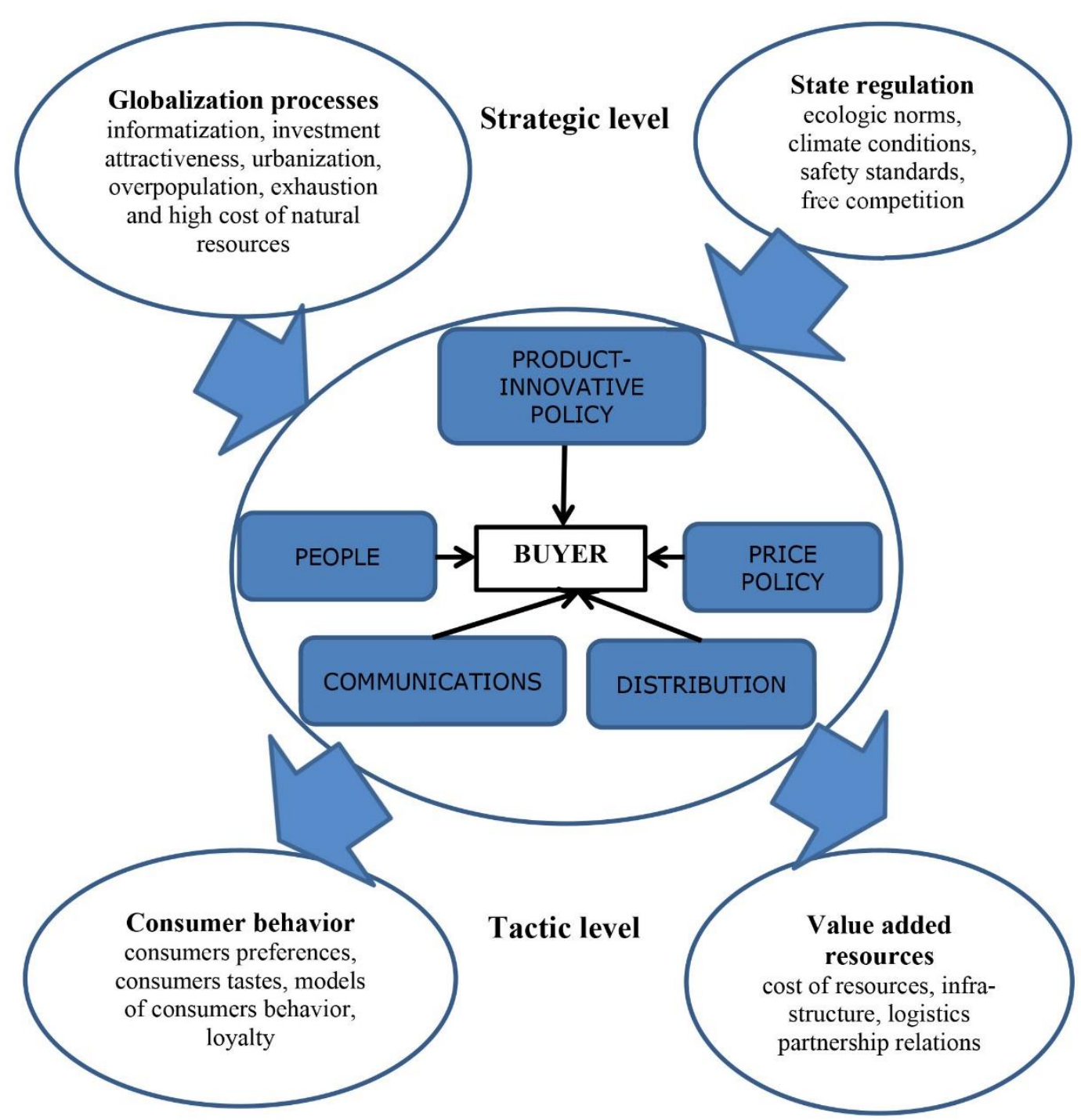

Figure 2. The concept of marketing efforts consolidation of car producers at the global car market (source: composed by the authors)

Therefore, we consider 2 groups of impact factors at the strategic level:

- globalization processes;

- state regulation.

Consolidation of strategic marketing efforts in the context of globalization processes involves research and consideration of economic processes globalization, informatization of economic processes, exhaustion and high cost of natural resources, strengthening of requirements for environmental friendliness of finished products and services, overpopulation and urbanization, etc.

Impact factors of state regulation, which need to be monitored by the enterprise, would include the application of environmental standards, safety standards, norms of use of natural resources, protection of free competition, support of national production, etc.
Consolidation of operational marketing efforts involves research into the growing demands of the buyer to the level of quality and value of products in a context of limited resources and capacity to meet the need. This consolidation involves balancing the ability of the manufacturer to meet demand by making efforts across all components of the marketing mix.

Impact factors at the tactical level include 2 groups of factors:

- Consumer behavior;

- "Value-added resources".

At the tactical level, we consider the main factors influencing the marketing complex of the car manufacturer, which are a group of factors related to consumer behavior, which are expressed in changes in consumer behavior, their tastes and consumer preferences, consumer loyalty, as well as 
patterns of consumer behavior depending on the geographical market.

In turn, the factors that influence the valueadded group of resources would be those resources that add value and advantages to the company, such as availability and cost of resources for the company, infrastructure, logistics and building partnership relations in the supplier-consumer system. This, in turn, provides the company with competitive advantages due to the synergistic effect of using partnerships and advantages in logistics. These factors are not static, their level of influence is changing dynamically.

The factors of strategic and tactical level have a strong influence on the formation of the marketing complex of the enterprise, depending on the geography of the market, where comes first prod- uct-innovation policy, which is the driver of formation of influence on the buyer's decisions and influences the use of already specific tools in other components of the marketing complex: pricing, communications, distribution, human resources management.

It is important here when developing marketing policy, to take also into account the latest trends in the use of tools of the marketing complex of the car producer (Table 2).

As a result, the concept of marketing efforts consolidation by the components of its marketing complex creates motives for the consumer to buy, shapes his loyalty and enhances the competitiveness of the car producing company at the global car market.

Table 2. Current trends in using marketing toolkit of car manufacturers (source: composed by the authors)

\begin{tabular}{|c|c|}
\hline $\begin{array}{l}\text { Type of mar- } \\
\text { keting toolkit }\end{array}$ & Peculiarities of using \\
\hline $\begin{array}{l}\text { In product- } \\
\text { innovative } \\
\text { policy }\end{array}$ & $\begin{array}{l}\text { - application of innovations; } \\
\text { - constant development of new products; } \\
\text { - reducing the life cycle of products; } \\
\text { - the increasing impact of the cost of related products (fuel/energy for cars); } \\
\text { - development of infrastructure for electric vehicles; } \\
\text { - cost of major components (batteries/ internal combustion engines); } \\
\text { - length of mileages. }\end{array}$ \\
\hline In price policy & $\begin{array}{l}\text { - analysis of financial factors of pricing; } \\
\text { - analysis of marketing factors of pricing; } \\
\text { - applying a pricing strategy based on goals at the specific market; } \\
\text { - setting prices depending on the geographic market; } \\
\text { - cost of ownership, including the cost of running a car / electric vehicle. }\end{array}$ \\
\hline $\begin{array}{l}\text { In the distribu- } \\
\text { tion system }\end{array}$ & $\begin{array}{l}\text { - transition to online sales; } \\
\text { - opening virtual stores; } \\
\text { - transition from single branding sales to the multi-branding proposal; } \\
\text { - } \text { shifting from product ownership to rental and car sharing; } \\
\text { - transition to a producer-end-user system without intermediaries. }\end{array}$ \\
\hline $\begin{array}{l}\text { In the commu- } \\
\text { nication } \\
\text { system }\end{array}$ & $\begin{array}{l}\text { - adaptation of tools to digital technologies; } \\
\text { - digitization of communications; } \\
\text { - personal selling is still important, but efficiency is diminishing towards online content and inter- } \\
\text { face. Combination of off-line and on-line sales; } \\
\text { - recommendations matter most; } \\
\text { - after-sales service is of high importance; } \\
\text { - direct communication between producer and end-consumer. In this case, producers are going } \\
\text { on-line, but dealers are still important in terms of logistics, servicing and final client decision } \\
\text { while test-driving a car. }\end{array}$ \\
\hline $\begin{array}{l}\text { In the human } \\
\text { resources } \\
\text { management } \\
\text { system }\end{array}$ & $\begin{array}{l}\text { - reducing the influence of the seller as a person; } \\
\text { - the use of artificial intelligence; } \\
\text { - personnel training; } \\
\text { - effective motivation; } \\
\text { - administration-personnel-client / supplier partnerships relations come to the forefront. }\end{array}$ \\
\hline
\end{tabular}




\section{Discussion}

The issue of implementation of the proposed concept by companies-producers of other industries, such as aviation, remains debatable. This is because the development of each industry has its specificity and it is necessary to take into account not only the typical global factors of influence but also specific to the particular industry.

\section{Conclusions}

The systematic analysis of the periodization of the transformation of marketing concepts, their refinement, is based on the fact that there is a transformation of the system of relations between the consumer and the producer of products or services. The critical evaluation of marketing concepts allows the authors propose to transform the existing periodization of the marketing concepts and divide the period of marketing into the period of marketing departments and the period of the marketing at the enterprise. Besides, the period of relationship marketing has been transformed into the digital marketing era.

The comparative analysis of the concepts of holistic marketing and relationship marketing allows us to state the necessity of combining modern developments in marketing theory with practical trends that have emerged in the car market.

The synthesis of marketing concept's components and deep understanding of the global car market peculiarities has become the gound of modeling the concept of marketing efforts consolidation by the components of the marketing complex at the level of strategic activity related to changes in the social, technical, economic factors of the external environment of the global car market, as well as at the level of tactical marketing, which is determined by the condition and need for managerial, organizational, technical changes in the interior environment of the car producer. The theoretical findings of the research are recommended to be verified in the form of qualitative research in the future.

\section{Contribution}

We declare the following involvement of the authors in writing a manuscript: Oleksandr Savych conception and design of the work, acquisition of data, and analysis and interpretation of data; Tetiana Shkoda - analysis and interpretation of data, drafting the article or revising it critically for important intellectual content, references, etc.

\section{Disclosure statement}

We declare that we do not have any competing financial, professional, or personal interests from other parties.

\section{References}

Al Badi, H. (2019). Implementation of the marketing concept and organizational culture in SMEs in Al Buraimi - Oman. Benchmarking: An International Journal, 26(7), 2401-2414. https://doi.org/10.1108/BIJ-05-2018-0136

Ambler, T. (2004). Marketing and the bottom line ( ${ }^{\text {nd }}$ ed.). FT Press.

Assael, H. (1993). Marketing principles and strategy ( $2^{\text {nd }}$ ed.). Thomson Learning.

Bagul, A., \& Mukherjee, I. (2019). Centralized vs decentralized sourcing strategy for multi-tier automotive supply network. International Journal of Productivity and Performance Management, 68(3), 578-607. https://doi.org/10.1108/IJPPM-02-2018-0083

Boone, L. E., \& Kurtz, D. L. (2013). Contemporary marketing $\left(16^{\text {th }}\right.$ ed.). Boston: Cengage Learning.

Dannikov, O. V. (2011). Relationship marketing of consumers, suppliers, distributors, partners [Marketing vzajemovidnosyn spozhyvachiv, postachalnykiv, dystrybjutoriv, partneriv]. Formation of Market Economy, 26, 258-271.

https://ir.kneu.edu.ua/bitstream/handle/2010/1540/ Dannikov.pdf?sequence $=1 \&$ is Allowed $=\mathrm{y}$

Demirbas, D., Wilkinson, L., \& Bennett, D. (2018). Supplier relations impact within the UK automotive industry. Benchmarking: An International Journal, 25(8), 3143-3161. https://doi.org/10.1108/BIJ-07-2017-0172

Elliott, G. (1990). The marketing concept - necessary, but sufficient? An environmental view. European Journal of Marketing, 24(8), 23-30. https://doi.org/10.1108/EUM0000000000612

Fedorchenko, A. V. (2009). System of marketing research [Systema marketyngovykh doslidzhen] (Monograph). KNEU.

Hoffman, K. D., \& Bateson, J. E. G. (2010). Services marketing: Concepts, strategies, and cases ( $4^{\text {th }}$ ed.). Thomson Higher Education.

Jobber, D., \& Ellis-Chadwick, F. (2012). Principles and practice of marketing ( ( $^{\text {th }}$ ed.). McGraw-Hill Education.

Kerin, R., Hartley, S., \& Rudelius W. (2012). Marketing (11 $1^{\text {th }}$ ed.). McGraw-Hill Education.

Kotler, Ph. (2002). Marketing management. Translated from English, L. A. Volkova (Eds.). Piter.

Kotler, Ph., \& Keller, K. L. (2015). Marketing management $\left(15^{\text {th }}\right.$ ed.). Pearson.

Lambin, J. J. (1992). Strategic marketing management. Blacklick. McGraw-Hill Companies. 
Morgan, R. E. (1996). Conceptual foundations of marketing and marketing theory. Management Decision, 34(10), 19-26. https://doi.org/10.1108/00251749610150658

Pavlenko, A. F., \& Voychak, A. V. (2003). Marketing: Study book. KNEU.

Pylypchuk, V.P., \& Dannikov, O. V. (2011). Sales management [Upravlinnia prodazhem]. Teaching. Manual. KNEU.

Radionova-Girsa, E. (2018). Relationship marketing on the Internet: Building a long-term relationship with customers. In $10^{\text {th }}$ International Scientific Conference "Business and Management 2018”, 03-04 May 2018, Vilnius, Lithuania. https://doi.org/10.3846/bm.2018.35

Sarkar, S., \& Rajagopalan, B. (2018). Consumer safety complaints and organizational learning: Evidence from the automotive industry. International Journal of Quality \& Reliability Management, 35(10), 2094-2118. https://doi.org/10.1108/IJQRM-03-2017-0048

Savych, O. P. (2017). Globalization impacts state governance of the automotive industry. Ekonomika ta derzhav, 115(11), 81-84. http://www.economy.in.ua/pdf/11_2017/20.pdf

Savych, O. P. (2018). Marketing on the global car market (The dissertation for getting a Doctor of Economics degree by specialty 08.00.04 - Economics and Management of Enterprises (by Types of Economics Activities)). SHEE "Kyiv National Economic University named after Vadym Hetman".

Semyrak, O. S. (2016). Planning and regulation of development of the automotive sector in Ukraine (The dissertation for getting a $\mathrm{PhD}$ in Economics degree by specialty 08.00 .03 - Economics and management of the national economy). Lviv Polytechnic National University of Ministry of Education and Science of Ukraine.

Shevchenko, I. Yu. (2019). Regulation of the development of the automotive industry on the principles of the harmonization approach (The dissertation for getting a Doctor of Economics degree by specialty 08.00.03 - Economics and management of the national economy). Lviv, HEI "National Academy of Management”.
Spiro, R. L., Stenton, Y. G., \& Rich, H. A. (2007). Sales management [Upravlenie prodazhami]. Izdatelskiy dom Hrebennikova.

Statista Research Department (SRD). (2020, February 15). Worldwide car sales 1990-2020. www.statista.com

Svensson, G. (2001). Re-evaluating the marketing concept. European Business Review, 13(2), 95-101. https://doi.org/10.1108/09555340110385263

Taqi, M., Gurkaynak, N., \& Gencer, M. (2019). Marketing concept evolution: a bibliometrics cooccurrence analysis. Marketing and Management of Innovations, 2, 185-197. https://doi.org/10.21272/mmi.2019.2-16

Terletska, V. O. (2018). Economic evaluation and formation of the market conditions of automotive products (The dissertation for getting a $\mathrm{PhD}$ in Economics degree by specialty 08.00.03 - Economics and management of the national economy). Lviv Polytechnic National University of Ministry of Education and Science of Ukraine.

Tomyuk, O. Ya. (2016). Marketing ensuring of product competitiveness of automotive enterprises (The dissertation for getting a $\mathrm{PhD}$ in Economics degree by specialty 08.00.04 - Economics and Management of Enterprises (by Types of Economics Activities)). Lviv Polytechnic National University of Ministry of Education and Science of Ukraine.

Wagner, I. (2020, February 15). Worldwide automobile production through 2018. www.statista.com

Weber, M., Parsons, T., \& Henderson, A. M. (1964). The theory of social and economic organization. New York, The Free Press, a division of Macmillan Publishing Co., Inc.; London: Collier Macmillan Publishers.

Zavjalov, P. S. (2014). Marketing in schemes, figures, tables [Marketing v skhemakh, risunkakh, tablitsakh] (Teaching Manual). INFRA-M.

Zaytsev, Yu., \& Moskalenko, O. (2018). Philosophical and methodological foundations of architectonics of the subject of modern polical economy [Filosofsko-metodologichni zasady arkhitektoniky predmeta suchasnoi politychnoi ekonomii] (Monograph). KNEU. 